American Journal of Applied Sciences 7 (3): 371-375, 2010

ISSN 1546-9239

(C) 2010Science Publications

\title{
Chloride Penetration Resistance Studies on Concretes Modified with Alkali Resistant Glass Fibers
}

\author{
${ }^{1}$ K. Chandramouli, ${ }^{2}$ P. Srinivasa Rao, ${ }^{3}$ N. Pannirselvam, ${ }^{4}$ T. Seshadri Sekhar and ${ }^{2}$ P. Sravana \\ ${ }^{1}$ Priyadrashini Institute of Technology for Women, Tenali, Guntur, Andhra Pradesh, India \\ ${ }^{2}$ Jawaharlal Nehru Technological University, College of Engineering, Hyderabad, Andhra Pradesh, India \\ ${ }^{3}$ Vellore Institute of Technology University, Vellore, Tamilnadu, India \\ ${ }^{4}$ Samual George Institute of Technology, Markapur, Prakasam District, Andhra Pradesh, India
}

\begin{abstract}
Problem statement: This research study presented the durability performance of glass fibre reinforced concrete. Approach: The influence of fiber content on the durability performance of glass fibre reinforced concrete specimens having different percentage of glass fibres with varying grades of concrete were investigated. Results: The parameter of investigation included rapid chloride permeability test for a period of 365 days. Specimens of $100 \times 150 \mathrm{~mm}$ cylinders were cast and tested to study their parameters. The specimens incorporated with addition of $0.03,0.06$ and $0.10 \%$ of glass fibres in M30, M40 and M50 grades of concrete. The durability performances of glass fibre reinforced concrete were compared with that of plain concrete. Conclusion/Recommendations: The results show that addition of glass fibres improves that durability performance appreciably.
\end{abstract}

Key words: Durability, fibre reinforced concrete, glass fibre reinforced concrete, rapid chloride permeability test, reinforced concrete

\section{INTRODUCTION}

Concrete is considered a brittle material, primarily because of its low tensile strain capacity and poor fracture toughness. For a long time concrete was considered to be very durable material requiring a little or no maintenance. The assumption is largely true, except when it is subjected to highly aggressive environments. The built concrete structures in highly polluted urban and industrial areas, aggressive marine environments, harmful sub-soil water in coastal area and many other hostile conditions where other materials of construction are found to be non-durable. Since the use of concrete in recent years, have spread to highly harsh and hostile conditions, the earlier impression that concrete is a very durable material is being threatened, particularly on account of premature failures of number of structures. In the past only strength of concrete was considered in the concrete mix design procedure assuming strength of concrete is an all-pervading factor for all other desirable properties of concrete including durability. In the recent revision of IS: 456-2000, one of the major points discussed, deliberated and revised in the durability aspects of concrete. One of the main reasons for deterioration of concrete in the past is that too much emphasis is placed on concrete compressive strength. As a matter of fact, advancement in concrete technology has been generally on the strength of concrete. It is now recognized that strength of concrete alone is not sufficient, the degree of harshness of the environmental condition to which concrete is exposed over its entire life is equally important. Therefore, both strength and durability have to be considered explicitly at the design stage.

Concrete is a widely used construction material for various types of structures due to its durability and strength. Reinforced concrete structures are exposed to harsh environments yet is often expected to last with little or no repair or maintenance for long periods of time (often 100 years or more). To do this, a durable structure needs to be produced. For reinforced concrete bridges, one of the major forms of environmental attack is chloride ingress, which leads to corrosion of the reinforcing steel and a subsequent reduction in the strength, serviceability and aesthetics of the structure. This may lead to early repair or premature replacement of the structure. A common method of preventing such deterioration is to prevent chlorides from penetrating the structure to the level of the reinforcing steel bar by using relatively impenetrable concrete. The ability of chloride ions to penetrate the concrete must then be known for design as well as quality control purposes. 
The penetration of the concrete by chloride ions, however, is a slow process. It cannot be determined directly in a time frame that would be useful as a quality control measure. Therefore, in order to assess chloride penetration, a test method that accelerates the process is needed, to allow the determination of diffusion values in a reasonable time. The Rapid Chloride Permeability Test (RCPT), as it is commonly called, has been in existence for over 20 years and was standardized by ASTM over 16 years ago. The test is used extensively in the concrete industry for assessing concrete quality.

Concrete can be modified to perform in a more ductile form by the addition of randomly distributed discrete fibres in the concrete matrix (Mohammadi et al., 2008). In Fibre Reinforced Concrete (FRC), fibres can be effective in arresting cracks at both macro and micro levels. Many of the current applications of fibre reinforced concrete involve the use of fibres ranging around $1 \%$. Hence an attempt has been made to study the durability performance of Glass Fibres (GF).

The penetrability of concrete is obviously related to the pore structure of the cement paste matrix. This will be influenced by the water-cement ratio of the concrete, the inclusion of supplementary cementing materials which serve to subdivide the pore structure and the degree of hydration of the concrete. The older the concrete, the greater amount of hydration that has occurred and thus the more highly developed will be the pore structure. This is especially true for concrete containing slower reacting supplementary cementing materials such as fly ash require a longer time to hydrate (Tahir and Yazicioglu, 2007; Neville, 1995).

Another influence on the pore structure is the temperature that is experienced at the time of casting. High temperature curing accelerates the curing process so that at young concrete ages, a high temperature cured concrete will be more mature and thus have a better resistance to chloride ion penetration than a normally cured, otherwise identical and concrete at the same at age. However, at later ages when the normally cured concrete has a chance to hydrate more fully, it will have a lower chloride ion diffusion coefficient than the high temperature cured concrete (Cao and Detwiler, 1995; Guneyisi et al., 2005).

The inclusion of supplementary cementing materials affects binding, though the exact influence is unclear (Buckley et al., 2007). Also, the content of the cement influences its binding capacity, with increased $\mathrm{C}_{3} \mathrm{~A}$ content leading to increased binding (Ormellese et al., 2006).
Table 1: Properties of anti crack high dispersion fibres (as per saintgobain)

Technical data

Elastic modulus

Filament diameter

Specific gravity

Length

Product form

Number of fibres $\mathrm{kg}^{-1}$

Aspect ratio

Specific surface area

Typical addition rate

Properties of glass fibres: Glass fibre is available in continuous or chopped lengths are presented in Table 1. Glass fibres are usually round and straight with diameters of $0.005-0.015 \mathrm{~mm}$. They could also be bonded together to produce glass fibre bundles with bundle diameters of up to $1.3 \mathrm{~mm}$. The glass fibres used in the present experimental investigation is High Dispersion Cem-FIL AR fibres. Anti-crack fibres do not protrude from the surface and require no further finishing. It is very effective at low dosages and easy and safe to handle. It controls and prevents early age cracking in concrete. The major draw back of glass fibre is its high vulnerability in the alkaline cementitious environment, which affects the long-term performance characteristics of the composite adversely. Alkali-resistant glass fibres can, however, be used to overcome this problem.

Objectives of the study: The objectives of the current research work to study the durability properties of:

- M30, M40 and M50 grade of concrete with varying percentages of addition of glass fibres 0, 0.03, 0.06 and $0.1 \%$ at 365 days

- Comparing each grade with their percentage of addition of glass fibres

\section{MATERIALS AND METHODS}

Cement: Ordinary Portland cement of 53 grades available in local market is used in the investigation. The cement used has been tested for various proportions as per IS 4031-1988 and found to be confirming to various specifications of IS: 12269-1987. The specific gravity was 2.96 and fineness was $3200 \mathrm{~cm}^{2} \mathrm{~g}^{-1}$.

Coarse aggregate: Crushed angular granite metal of $20 \mathrm{~mm}$ size from a local source was used as coarse aggregate. The specific gravity of 2.71 and fineness modulus 7.13 was used. 


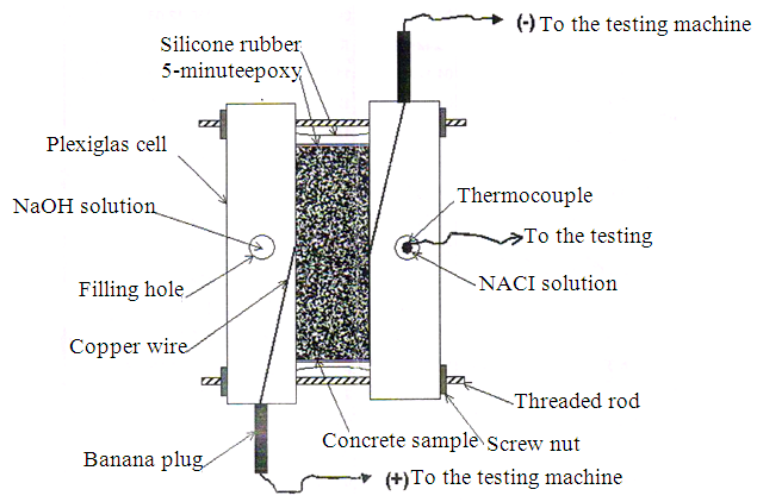

Fig. 1: Schematic diagram of RCPT (ASTM C 1202-94)

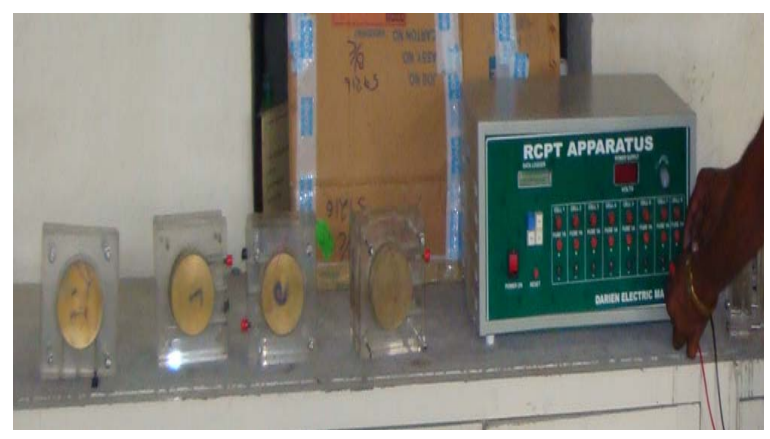

Fig. 2: Experimental set up specimens

Fine aggregate: River sand was used as fine aggregate. The specific gravity of 2.60 and fineness modulus 3.25 was used in the investigation.

Rapid chloride permeability test: Corrosion is mainly caused by the ingress of chloride ions into concrete annulling the original passivity present. Rapid Chloride Permeability Test (RCPT) has been developed as a quick test able to measure the rate of transport of chloride ions in concrete. This test was conducted as per ASTM C 1202-94. Concrete disc of size $100 \mathrm{~mm}$ diameter and $50 \mathrm{~mm}$ thickness with and without GF were cast and allowed to cure. After curing the concrete specimens were subjected to RCPT by impressing $60 \mathrm{~V}$. Two halves of the specimens are sealed with PVC container of diameter $90 \mathrm{~mm}$. One side of the container is filled with $3 \%$ sodium chloride solution (that side of the cell will be connected to the cathode terminal of the power supply) and other side sodium hydroxide solution was poured and connected to anode terminal as shown in Fig. 1. Figure 2 shows the experimental set up for determining chloride using RCPT. Table 2 represents the rating of concrete as per ASJMC 1209-94.

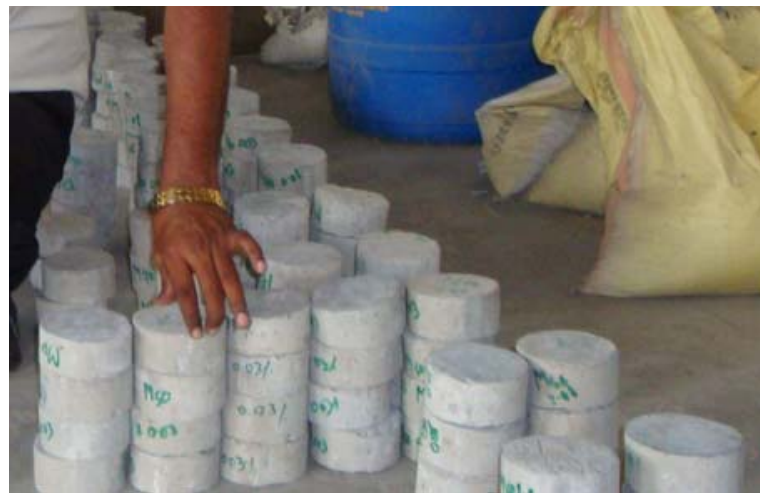

Fig. 3: Cast specimen

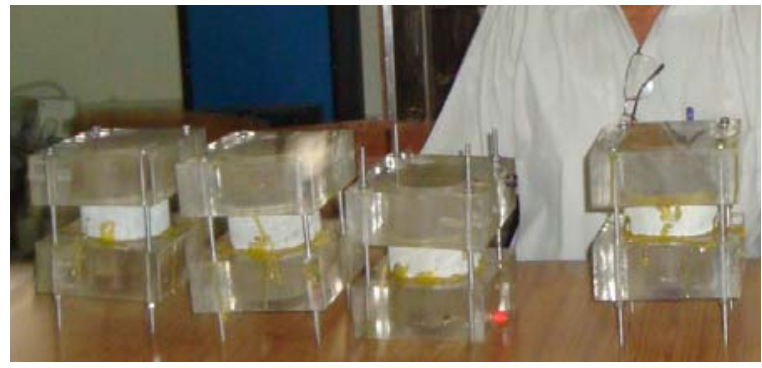

Fig. 4: Preparation of specimen to the cells of RCPT

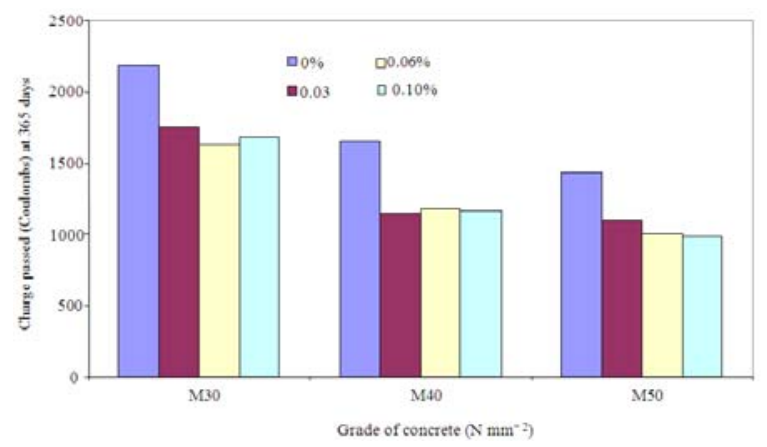

Fig. 5: RCPT value for different grade at 365 days

Table 2: RCPT ratings (as per ASTM C1202-94)

\begin{tabular}{ll}
\hline Charge passed (coulombs) & Chloride ion penetrability \\
\hline$>4000$ & High \\
$2000-4000$ & Moderate \\
$1000-2000$ & Low \\
$100-1000$ & Very low \\
$<100$ & Negligible \\
\hline
\end{tabular}

The cast specimens are presented in Fig. 3 and the preparation of specimens into the cell according to the ASTMC 1202-94 as shown in Fig. 4. The details of the values after testing using RCPT specimen are presented in Table 3. 
Am. J. Applied Sci., 7 (3): 371-375, 2010

Table 3: Rapid chloride permeability test for ordinary concrete and glass fibre reinforced cement concrete

\begin{tabular}{llll}
\hline $\begin{array}{l}\text { Grade of } \\
\text { concrete }\end{array}$ & $\begin{array}{l}\text { Glass } \\
\text { fibres (\%) }\end{array}$ & $\begin{array}{l}\text { Charge passed } \\
\text { (Coulombs) at 365 days }\end{array}$ & $\begin{array}{l}\text { Chloride permeability as per } \\
\text { ASTM C1202 at 365 days }\end{array}$ \\
\hline M30 & 0.00 & 2182 & Moderate \\
M30 & 0.03 & 1755 & Low \\
M30 & 0.06 & 1632 & Low \\
M30 & 0.10 & 1682 & Low \\
M40 & 0.00 & 1653 & Low \\
M40 & 0.03 & 1148 & Low \\
M40 & 0.06 & 1175 & Low \\
M40 & 0.10 & 1167 & Low \\
M50 & 0.00 & 1432 & Low \\
M50 & 0.03 & 1100 & Low \\
M50 & 0.06 & 1002 & Very low \\
M50 & 0.10 & 987 & Very low \\
\hline
\end{tabular}

Testing of specimens: The specimens were fit in the chamber with the required brass as well as rubber oaring. The record time is set as $30 \mathrm{~min}$ and also the log time as $6 \mathrm{~h}$ and $30 \mathrm{~min}$ and the current of $60 \mathrm{~V}$ is passed continuously. The data logger records the readings of corresponding cells at the every record time with its initial readings. At the end of log time, the system halts after taking the final reading. From the results using current and time, chloride permeability is calculated in terms of total charge passed in Coulombs at the end of $6 \mathrm{~h}$ by using the formula given in Eq. 1 .

Average current flowing through one cell is calculated by:

$\mathrm{I}=900 \times 2 \times I$ Cumulative Coulombs

$\mathrm{I}_{\text {CUMMULATIVE }}=\mathrm{I}_{0}+\mathrm{I}_{30}+\mathrm{I}_{60}+\mathrm{I}_{90}+\mathrm{I}_{120}+\mathrm{I}_{150}+\mathrm{I}_{180}+\mathrm{I}_{210}+\mathrm{I}_{240}$ $+\mathrm{I}_{270}+\mathrm{I}_{300}+\mathrm{I}_{330}+\mathrm{I}_{360}$

Where:

$\mathrm{I}_{0} \quad=$ Initial current reading in $\mathrm{mA}$

$\mathrm{I}_{30}=$ Current reading at $30 \mathrm{~min}$ in $\mathrm{mA}$

$\mathrm{I}_{60}=$ Current reading at $60 \mathrm{~min}$ in $\mathrm{mA}$

$\mathrm{I}_{90}=$ Current reading at $90 \mathrm{~min}$ in $\mathrm{mA}$

$\mathrm{I}_{120}=$ Current reading at $120 \mathrm{~min}$ in $\mathrm{mA}$

$\mathrm{I}_{150}=$ Current reading at $150 \mathrm{~min}$ in $\mathrm{mA}$

$\mathrm{I}_{180}=$ Current reading at $180 \mathrm{~min}$ in $\mathrm{mA}$

$\mathrm{I}_{210}=$ Current reading at $210 \mathrm{~min}$ in $\mathrm{mA}$

$\mathrm{I}_{240}=$ Current reading at $240 \mathrm{~min}$ in $\mathrm{mA}$

$\mathrm{I}_{270}=$ Current reading at $270 \mathrm{~min}$ in $\mathrm{mA}$

$\mathrm{I}_{300}=$ Current reading at $300 \mathrm{~min}$ in $\mathrm{mA}$

$\mathrm{I}_{330}=$ Current reading at $330 \mathrm{~min}$ in $\mathrm{mA}$

$\mathrm{I}_{360}=$ Current reading at $360 \mathrm{~min}$ in $\mathrm{mA}$

\section{RESULTS AND DISCUSSION}

Effect of glass fibre on bleeding of glass fibre concrete: On the basis of the Experimental study it was observed that the addition of glass fibres gives a reduction in bleeding. A reduction in bleeding improves the surface integrity of concrete, improves its homogeneity and reduces the cracks on the surface.

Rapid chloride permeability: From the Table 3 we can observe that chloride permeability as per ASTM 1202-94 (RCPT) for glass fibre reinforced concrete shows less permeability of chlorides into the concrete when compared with ordinary concrete without glass fibres. It was also observed that higher the grade of concrete lower is the permeability of chlorides into concrete and the same was proved that optimum usage of glass fibres also helps in improving the durability of concrete. The trend was also shown in Fig. 5.

\section{CONCLUSION}

The performance of GFRC increased with regard to durability. The following salient conclusions are drawn from the present investigations:

- Chloride permeability of glass fibre reinforced concrete shows less permeability of chlorides for higher grade of concrete

- The RCPT is moderate for M30 grade of concrete for $0 \%$ GFRC

- For M50 grade of concrete with 0.06 and $0.10 \%$ is very low

- In general for addition of GF reduces the cracks causing interconnecting voids to be minimum

- Due to the addition of $0.10 \%$ of glass fibres there is decrease of permeability by 22.91, 29.40 and $31.08 \%$ at 365 days for M30, M40 and M50 grade of concrete respectively

\section{REFERENCES}

Buckley, L.J., M.A. Carter, M.A. Wilson and J.D. Scantlebury, 2007. Methods of obtaining pore solution from cement pastes and mortars for chloride analysis. Cement Concrete Res., 37: 1544-1550. DOI: 10.1016/j.cemconres.2007.08.009

Cao, Y. and R.J. Detwiler, 1995. Backscatter electron imaging of cement pastes cured at elevated temperatures. Cem. Concr. Res., 25: 627-638, DOI: 10.1016/0008-8846(95)00051-D

Guneyisi, E., T. Ozturan and M. Gesoglu, 2005. A study on reinforcement corrosion and related properties of plain and blended cement concretes under different curing conditions. Cement Concrete Compos., 27: 449-461. DOI: 10.1016/j.cemconcomp.2004.05.006 
Mohammadi, Y., S.P. Singh and S.K. Kaushik, 2008. Properties of steel fibrous concrete containing mixed fibres in fresh and hardened state. Construct. Build. Mater., 22: 956-965. DOI: 10.1016/j.conbuildmat.2006.12.004

Neville, A., 1995. Chloride attack of reinforced concrete: An overview. Mater. Struct., 28: 63-70. DOI: 10.1007/BF02473172

Ormellese, M., M. Berra, F, Bolzoni and T. Pastore, 2006. Corrosion inhibitors for chlorides induced corrosion in reinforced concrete structures. Cement Concrete Res., 36: 536-547. DOI: 10.1016/j.cemconres.2005.11.007
Tahir G. and S. Yazicioglu, 2007. The influence of mineral admixtures on the short and long-term performance of concrete. Build. Environ., 42: 3080-3085.

DOI: 